\title{
EFFECT OF INPUT VALUES ON THE RESULTING COST OF EQUITY VALUE CALCULATED BY THE MODEL INFA
}

\author{
LEICHEROVA, V[eronika]; JIRINCOVA, M[ilena] \& JANUSKA, M[artin]
}

\begin{abstract}
The following article is dedicated to one of the few modular models used for determining the cost of capital which is widely used in the Czech Republic. The accuracy of this model is strongly influenced by the input values which are derived from financial statements of rated companies. The paper presents a case study focused on adjustment of input values from the balance sheet which should contribute to more accurate values of the model.
\end{abstract}

Keywords: Cost of Equity, Modular model, INFA

\section{INTRODUCTION}

One of the main tasks of financial management is to ensure sufficient financial resources and place them in such way that they are used effectively and to ensure the financial equilibrium of the company. The basis of financial management is financial decision of choosing the most suitable variant movement of money, capital and financial resources and control the implementation of these decisions. [1] Cost of capital is used in financial management as one of the most important decision criteria.

\section{COST OF CAPITAL}

Cost of capital is considered as cost of the enterprise to obtain particular components of enterprise capital both own and foreign. At the same time the cost of capital represents the minimum rate of return of the capital required by the investor. It is a dual perception of costs, from the perspective of an investor and the perspective of the company. The cost of capital depends on the risk of individual assets and they generally consist from a riskfree rate $r_{f}$ and risk premium RP. [1]

\subsection{Cost of equity}

As already stated in general the own capital costs are higher than the costs of foreign capital. Literature [2] suggests two basic reasons. Firstly the risk of the owner contributing resources to the enterprise is greater than the risk of the lender. Lender is usually granted regular interest income regardless the fact if debtor makes a profit. The lender is also depositing funds to the company for a limited time period after which the funds are returned to him. Second the interest expense is taxdeductible expense which reduces the profit as a basis for calculating income tax. This effect is known as the interest tax shield. In contrast the owner is depositing resources for an indefinite period of time. His income is not beforehand guaranteed because it is dependent on the economic situation of the company.

\subsection{Methods of calculating cost of equity}

For determining the required rate of Cost of Equity the following methodology can be used: Gordon Growth Model, CAPM (Capital Asset Pricing Model), model APT (Arbitrage Pricing Theory) and other models which include for example market and modular models. [3]

The first three models are most often used in AngloSaxon countries and the United States of America. In Europe these models are well known and used but more often we encounter the so-called modular models whose design concept is based on the risk-free rate which is further increased by the additional charges expressing certain risk aspect. There are several models and the most used are those which are based on multi-criteria evaluation of various aspects of company operations. [3]

One of the versions of this method is the so-called complex modular method which is a certain analogy of the expert determination of $\beta$-coefficient.[4] The company's risk premium is determined based on the evaluation of set of more than twenty risk factors distributed into two groups of factors the business and financial risk. [5] In the Czech Republic among the most used is modular model of the Ministry of Industry and Trade (MIT) based on the average profitability of companies within the industry. The following paper deals with this model. It is possible to say that this model is the opposite of a complex modular method which determines the risk premium of the company as the sum of the amounts provided by financial indicators. [4]

\subsection{INFA}

MIT of the Czech Republic uses INFA system namely one part of INFA system the pyramidal decomposition of EVA pointer for evaluation of the enterprises. The authors of model INFA and owners of the copyrights to the INFA are Ivan and Inka Neumaier. American consulting firm Stern Stewart \& Co. has registered copyrights for the acronym EVA.

Pyramid decomposition is a combination of financial controlling and risk controlling. Their connection is realized by means of indicators which act both as indicators of performance and as a fundamentals for the risk estimation. Adjusted INFA rating model which seems most appropriate for MIT principally accesses to risks as rating agencies. It generates a risk level from the fundamentals of monitored indicators. [6]

Important fundamental characteristics affecting risks were identified and rating function was created with 



\section{CASE STUDY}

The following case study focuses on the application of the INFA model on the selected Czech company which is engaged in the manufacture of wooden furniture and mattress. The main purpose of the study is to demonstrate how significantly input values taken from the financial statements can affect the final value of the cost of equity $r_{e}$ and examined $E V A$ index in version Equity. Financial statements balance sheet and profit and losses statement were used as input values for the purposes of the study. Values were rounded and truncated. Tab. 1 shows the individual components of assets of the enterprise in CZK to the date of 31 December of selected year.

\begin{tabular}{|l|r|r|r|}
\hline \multirow{2}{*}{\multicolumn{1}{|c|}{ Balance Sheet }} & \multicolumn{3}{|c|}{ Years } \\
\cline { 2 - 4 } & \multicolumn{1}{|c|}{$\mathbf{2 0 0 7}$} & \multicolumn{1}{c|}{$\mathbf{2 0 0 8}$} & \multicolumn{1}{c|}{$\mathbf{2 0 0 9}$} \\
\hline Total Assets & $\mathbf{1 0 7 8 0 0}$ & $\mathbf{1 1 5} \mathbf{1 0 0}$ & $\mathbf{2 1 4 3 0 0}$ \\
\hline Fixed Assets & 53800 & 65000 & 106200 \\
\hline Intangible Assets & 400 & 800 & 500 \\
\hline Tangible Assets & 53400 & 64200 & 105600 \\
\hline Financial Assets & 0 & 0 & 100 \\
\hline Current Assets & 53200 & 49400 & 105700 \\
\hline Inventory & 26300 & 25800 & 25300 \\
\hline Accounts Receivables & 11200 & 13400 & 58500 \\
\hline Cash and Cash Equivalents & 11200 & 13400 & 58500 \\
\hline Other Assets & 15700 & 10200 & 21900 \\
\hline
\end{tabular}

Tab. 1. Balance sheet - Assets

Tab. 2 shows the components of liabilities and equity.

\begin{tabular}{|l|r|r|r|}
\hline \multirow{2}{*}{\multicolumn{1}{|c|}{ Balance Sheet }} & \multicolumn{3}{|c|}{ Years } \\
\cline { 2 - 4 } & \multicolumn{1}{c|}{2007} & \multicolumn{1}{c|}{2008} & \multicolumn{1}{c|}{2009} \\
\hline Total Liabilities and Equity & 107800 & 115100 & 214300 \\
\hline Equity & 100000 & 107800 & 106200 \\
\hline - thereof Retained Earnings & 71400 & 77700 & 82100 \\
\hline $\begin{array}{l}\text { - thereof Current year } \\
\text { Earnings }\end{array}$ & 6300 & 7700 & 1800 \\
\hline Liabilities & 7200 & 7100 & 107800 \\
\hline Long term Liabilities & 1400 & 1300 & 1300 \\
\hline Short term Liabilites & 5800 & 5800 & 106500 \\
\hline Bank Loans & 0 & 0 & 0 \\
\hline Other Liabilities & 600 & 200 & 300 \\
\hline
\end{tabular}

Tab. 2. Balance sheet - Liabilities and Equity

Profit and loss statement is also given in an abbreviated version and gives only the final values for the results of the activities. Moreover there is given Interest expense item as the input variable for calculating the estimated interest rate based on $U M$ equation (12).

\begin{tabular}{|l|r|r|r|}
\hline \multirow{2}{*}{ Profit and Loss Statement } & \multicolumn{3}{|c|}{ Years } \\
\cline { 2 - 4 } & \multicolumn{1}{|c|}{2007} & \multicolumn{1}{|c|}{2008} & \multicolumn{1}{c|}{2009} \\
\hline Interest expenses & 51 & 98 & 0 \\
\hline Operating Profit & 8300 & 9900 & 3500 \\
\hline Financial Profit & -200 & -200 & -600 \\
\hline Income Tax & 1800 & 2000 & 1100 \\
\hline Net Profit & 6300 & 7700 & 1800 \\
\hline Profit before Tax & 8100 & 9700 & 2900 \\
\hline
\end{tabular}

Tab. 3. Profit and loss statement

INFA model uses as input values items from profit and loss statement. As is generally known the financial statement Balance sheet belongs among the status reports. Balance sheet shows the assets respectively sources of coverage to a defined point in time. Here at 31 December of each year. In contrast, profit and loss statement belongs among the flow reports as well as cash-flow statement and they represent flow for particular period. There is possible to see basic cause of possible distortion in EVA indicator because we compare status and flow report values. Tab. 4 shows the calculated value of EVA in Equity version according to the equation (18). The values from the Balance Sheet for the year 2008 and the Profit and Loss Statement for the year 2008 are used as input values in the column Year 2008. In contrast in the column $\varnothing 2008$ so-called "average balance sheet items for the year 2008", values were used. That means that conversion of input values to the arithmetic mean according to the following equation was used:

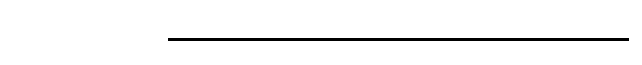

The financial statements are prepared in the framework of the annual financial statements to the 31 December of the relevant year. External analyst usually does not dispose with the initialization statements to the first January of the relevant year. So we use the logic that the final Balance sheet items at the closing Balance sheet are equal to the initial state of the Balance sheet items in the opening Balance sheet. That means that above mentioned equation (19) is modified to the following form:

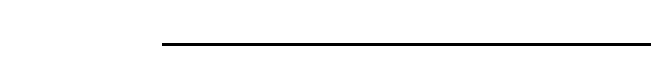

Risk-free interest rate in Tab. 4 is ten-year government bond yield whose values are listed on the website of MIT [6]. To determine the risk premium was necessary to calculate the value of current liquidity $L 3$ and according selected algorithm calculate the premium. A similar procedure should be followed when determining other risk premiums. Size of the cost of equity $r_{e}$ is then given by the sum of all risk premiums. In tab. 4 can be seen that the difference between the premium calculated from the values from the end of the year 2008 and average values are not too large because the values of the year 2007 are similar to the 2008 values.

\begin{tabular}{|l|r|r|}
\hline \multirow{2}{*}{\multicolumn{1}{|c|}{ Items }} & \multicolumn{2}{c|}{ Years } \\
\cline { 2 - 3 } & \multicolumn{1}{c|}{2008} & \multicolumn{1}{c|}{$2008 \tilde{N}$} \\
\hline Risk free rate $R f$ & $4,550 \%$ & $4,550 \%$ \\
\hline Current Liquidity L3 & 8,517 & 8,845 \\
\hline Premium for financial stability & $0,000 \%$ & $0,000 \%$ \\
\hline UZ (in thousands of CZK) & 107800,1 & 103900,1 \\
\hline Premium for size of the enterprise & $4,973 \%$ & $4,987 \%$ \\
\hline ROA & 0,086 & 0,089 \\
\hline X1 & 0,000 & 0,000 \\
\hline Premium for business risk & $4,950 \%$ & $4,950 \%$ \\
\hline Cost of debt capital & $0,000 \%$ & $0,000 \%$ \\
\hline WACC leveraged & $14,473 \%$ & $14,487 \%$ \\
\hline $\mathrm{R}_{\mathrm{e}}$ unleveraged =WACC unleveraged & $14,473 \%$ & $14,487 \%$ \\
\hline$R_{e}$ leveraged & $14,473 \%$ & $14,487 \%$ \\
\hline Spread & $-7,330 \%$ & $-7,768 \%$ \\
\hline ROE & $7,143 \%$ & $7,411 \%$ \\
\hline Equity (in thousands of CZK) & 107800 & 103900 \\
\hline EVA (in thousands of CZK) & -7902 & -7351 \\
\hline
\end{tabular}

Tab. 4. EVA - Equity calculation for year 2008 
For comparison the procedure was repeated for the year 2009 where there was a more than twofold increase in current assets and current liabilities compared to year 2008. Average adjusted values will therefore differ significantly from the input values. As shown in Tab. 5 in case of the use of average values of year 2009 financial stability premium $r_{\text {FINSTAB }}$ was decreased nearly to the half due to the fact that size of the premium depends on the size of indicator $L 3$. When calculating the value of $r_{e}$ and $W A C C$ there was a very significant difference which of course affected the resulting value of EVA indicator in version Equity as shown in the last row of Tab. 5.

\begin{tabular}{|l|r|r|}
\hline \multirow{2}{*}{\multicolumn{1}{|c|}{ Items }} & \multicolumn{2}{c|}{ Years } \\
\cline { 2 - 3 } & \multicolumn{1}{c|}{2009} & \multicolumn{1}{c|}{$2009 \tilde{N}$} \\
\hline Risk free rate Rf & $4,670 \%$ & $4,670 \%$ \\
\hline Current Liquidity L3 & 0,992 & 1,381 \\
\hline Premium for financial stability & $10,000 \%$ & $5,564 \%$ \\
\hline UZ (in thousands of CZK) & 106200,1 & 107000,1 \\
\hline Premium for size of the enterprise & $4,979 \%$ & $4,976 \%$ \\
\hline ROA & 0,016 & 0,021 \\
\hline X1 & 0,000 & 0,000 \\
\hline Premium for business risk & $4,990 \%$ & $4,990 \%$ \\
\hline Cost of debt capital & $0,000 \%$ & $0,000 \%$ \\
\hline WACC leveraged & $24,639 \%$ & $13,123 \%$ \\
\hline $\mathrm{R}_{\mathrm{e}}$ unleveraged =WACC unleveraged & $24,639 \%$ & $20,200 \%$ \\
\hline$R_{e}$ leveraged & $24,639 \%$ & $13,123 \%$ \\
\hline Spread & $-22,944 \%$ & $-11,441 \%$ \\
\hline ROE & $1,695 \%$ & $1,682 \%$ \\
\hline Equity (in thousands of CZK) & 106200 & 107000 \\
\hline EVA (in thousands of CZK) & -24366 & -12242 \\
\hline Tab. 5. EVA - Equity calculation for $y+2009$ & \\
\hline
\end{tabular}

Tab. 5. EVA - Equity calculation for year 2009

We can say that for small changes during the year which have an impact on the final value of Balance sheet item at the end of the year the arithmetic average of the previous year and examined year is not very different. Input values do not have such a significant impact on the final value of surcharges and therefore the final value of the cost of equity. On the contrary as shown by calculations for year 2009 in case of significant differences between the initial and final value of selected Balance sheet item there are also significant difference of mean value. The values of the surcharges can vary significantly and this leads ultimately to a significant distortion of the values of the examined indicators.

\section{CONCLUSION}

Cost of equity is sharply monitored parameter of company performance in financial management. Serves not only as one of the input values to determine the final value of the indicator of financial performance EVA but they have an irreplaceable role for the efficiency evaluation and determination of business value of the company. Methods for calculating the cost of capital are constantly evolving and becoming more accurate but their accuracy is often affected by the reliability and accuracy of input parameters.
The Balance sheet is known as a static statement and input values reflect the assets to the intended date. If these values should serve as input values to the modular model INFA it would be appropriate to recalculate them to the average values according to the proposed procedure. Average values more accurately describe the condition of assets during the whole reporting period and not just a state to the specific date. This procedure has been recommended as the calculation of the profitability in the financial analysis. See below [8].

INFA model authors themselves state that a detailed process for estimating $r_{e}$ based on the above mentioned model cannot be taken as a fixed algorithm but as a principle approach and it is necessary to take into account differences of evaluated companies. [6] The proposed way of input data treatment will be furthermore tested at the data from previous years to verify the size of distortion caused by usage of not treated data.

\section{ACKNOWLEDGEMENTS}

This paper was supported by the University of West Bohemia. Project No. SGS-2012-028: Research on the impact of monitoring, evaluation and prediction of organizational processes on the overall performance.

\section{REFERENCES}

[1] Dluhošová, D. (2010). Financial Management and Business Decision Making: Analysis, Investment Valuation, Risk and Flexibility (Finanl'n' Śzen' a rozhodov" $n^{\prime}$ podniku: analīza, investov" "n', oceRov"n', riziko, flexibilita). Ekopress, ISBN 97880-86929-68-2, Prague

[2] Brealey, R. A.; Myers, S. C.; Allen, F. (2007) Principles of corporate finance. McGraw-Hill, ISBN 978-00-7126-67-5, New York

[3] Kislingerová, E. (2001). Business valuation (Oceňování podniku). C.H.Beck, ISBN 80-7179-529-1, Prague

[4] Fotr, J., Soucek, I. (2011). Investment decisions and project management: how to prepare, fund and evaluate projects, manage their risk and create a portfolio of project (Investil'n' rozhodov" $n$ ' a S'zen' projektŤ: jak pŜipravit, financovat a hodnotit projekty, $\hat{S}^{\prime}$ dit jejich riziko a vytv" Set portfolio projekt $\breve{T}$ ). Grada Publishing, ISBN 978-80-247-3293-0, Prague

[5] Marik, M. (2011). Company Valuation Methods: the Process of Valuation - Basic Methods and Procedures (Metody oceRov" $n$ " podniku: proces ocenōn' - z"kladn' metody a postupy). Ekopress, ISBN 978-80-86929-67-5, Prague

[6] http://www.mpo.cz/dokument105732.html, (2012). Ministry of Industry and Trade of the Czech Republic, Financial Analysis of the Corporate Sector for the Year 2011(Finanl'n' analīza podnikov ${ }^{\circ} f^{\circ}$ ry za rok 2011), Accessed on: August 1, 2012

[7] Neumaierová, I.; Neumaier, I. (2002). Performance and Market Value of the Firm (Výkonnost a tržní hodnota firmy). Grada Publishing, ISBN 978-80-24701-25-7, Prague

[8] Marek, P. (2009). Study Guide to Company Finance (Studijní průvodce financemi podniku). Ekopress, ISBN 978-80-86929-491 , Prague 